\title{
WATER MANAGEMENT OF THE MEKONG RIVER
}

\author{
Gao Yun ${ }^{*}$, Stewart Williams ${ }^{2}$, Dai Wenbin ${ }^{2}$
}

${ }^{1}$ Institute of Hydrogeology and Environmental Geology, Chinese Academy of Geosciences, Shijiazhuang 050061, China

${ }^{2}$ School of Land and Food, Department of Environmental Study and Geography, Tasmania University, Tasmania 7005, Australia.

*Corresponding author email: gaoyun0526@163.com

This is an open access article distributed under the Creative Commons Attribution License, which permits unrestricted use, distribution, and reproduction in any medium, provided the original work is properly cited

\section{ARTICLE DETAILS}

\section{Article history:}

Received 12 October 2017

Accepted 12 November 2017

Available online 20 Disember 2017

Keywords:

Transboundary river, Mekong

region, Riparian countries,

Challenges of water management

\section{ABSTRACT}

In the coming decades, river pollution is a serious problem not only in Asia but around the world. As the river flows through many countries, the development and water quality of the Mekong River is related directly to stability and peace of the region. This study analysed regulatory authority and legislation in Mekong River and discussed the inadequacy of Mekong River current management. Through collecting data and documents, it analysed and concluded current river management situation of Mekong River. At last, this paper advised several recommendations and tried to find out which approaches will make Mekong Basin under a good environment of sustainable development.

\section{INTRODUCTION}

\subsection{Geography of the Mekong River Basin}

In mainland Southeast Asia, the Mekong River Basin is the significant source of water, flowing through or forming the international border of six countries: China (in particular, Yunnan Province), Myanmar, Laos, Thailand, Cambodia, and Vietnam [1]. The headwater of the river is in China's Qinghai Province and the watershed is over $810000 \mathrm{~km} 2$ [2]. So, the Mekong River is the eighth largest river in the world and the largest international river in Southeast Asia which has $4880 \mathrm{~km}$ distance from the source to entrance [2]. More than 80 million people use the Mekong River for irrigation water, drinking water, fishing and transportation [3]. Upper Mekong River (China section) is named Lancang River in China. $20 \%$ of volume of water comes from watersheds in Yunnan Province and flows into Mekong's mainstream [4].

\subsection{The challenges for water management in the Mekong River}

As a transboundary river, the Mekong River has the same issues on conflicts of water resources uneven distribution and water pollution. Uneven distribution of water quantity could be the greatest potential issue. Combing with growing pressure on water resources, competing needs for development are also a potential conflict. International agreements or institutional arrangements lack could also be a hidden trouble [5]. Due to the fast-economic growth and high resource potential, the pressures of Mekong's resources may specifically high in current and the future [6].

Pollution and water quality issues are also serious now in this region. In the upper Mekong River basin (Yunnan Province, China), there are many industrial enterprises were surveyed in 2000, and some of them were shut down because of water pollution. Besides these industrial factories, a mass of hydropower stations has been built on the upper Mekong River. Mekong River Commission pointed that it should have further investigation for some toxicity of water on Lao section of Mekong River [7].

\section{RESEARCH AIMS AND METHODS}

\subsection{Problems}

During fast social economic development, pollution of the Mekong River has become more serious. Agriculture is a main pollution source. Because of the backward agricultural technology, farmers use a great deal of pesticides and fertilizers which brings serious pollution to the surface water. With the increase in the population, more people live close to the river. Thus, a large number of domestic wastewater discharged into river. There are many mining factories built close to Mekong River, some of them are small size mining enterprises which do not have advanced technology and financial support. So, a great amount of industrial wastewater is discharged into the river also. These problems present significant challenges in the planning for water quality management in the Mekong River.

The aims of this research are as follows:

(1) Gain a better understanding of the achievements, gaps and challenges for planning in transboundary water resources management;

(2) Identify the principal challenges of planning for water quality management in the Mekong River, and review the planning practices and strategies currently in place for mitigating those challenges;

(3) Evaluate planning for water quality management in the Mekong River in a comparison with transboundary water resources management practices elsewhere;

(4) Develop recommendations to improve planning for water quality management in the Mekong River.

The 6 riparian countries of Mekong River are all developing countries. Most of them are agricultural nations and have less-developed industries. In addition, environmental problems such as water resource pollution and ecosystem destruction are not yet too severe in that area [8]. For the Mekong River's better development, it cannot repeat the model of "pollution first, treatment later" as it was in the history of developed countries.

\section{INADEQUACY OF MEKONG RIVER CURRENT MANAGEMENT}

\subsection{Lack of unified coordination authority}

Mekong River's future is intertwined with the lives of citizens of six riparian states, meaning it requires unified, coordinated administration. This authority could govern the water resources in accordance with actual conditions of the basin and principles of equity and justice. Meanwhile, it may provide a comprehensive guide for development and utilization of the whole river basin [9]. There are three main organizations in the Mekong River Basin, each with different rationales, members, goals and weaknesses (Table 1 and Table 2). 
Table 1: MRC, GMS and QEC [10]

\begin{tabular}{|lllll|}
\hline Project & $\begin{array}{l}\text { Origin of } \\
\text { Initiative }\end{array}$ & $\begin{array}{l}\text { Year of Formal } \\
\text { Establishment }\end{array}$ & Rationale & Outcome \\
\hline Mekong River & Extra- & 1995 & Integrated Water & Stalled \\
\hline Commission (MRC) & regional & & $\begin{array}{l}\text { Resources } \\
\text { Management }\end{array}$ & Successful \\
\hline $\begin{array}{l}\text { Greater Mekong Sub- } \\
\text { region (GMS) }\end{array}$ & $\begin{array}{l}\text { Intra- } \\
\text { regional }\end{array}$ & 1992 & $\begin{array}{l}\text { Economic } \\
\text { Development }\end{array}$ & Failed \\
\hline $\begin{array}{l}\text { Quadripartite } \\
\text { Economic } \\
\text { Cooperation (QEC) }\end{array}$ & $\begin{array}{l}\text { Intra- } \\
\text { regional }\end{array}$ & 2001 & $\begin{array}{l}\text { Economic } \\
\text { Development }\end{array}$ & \\
\hline
\end{tabular}

Table 2: Member States [10]

\begin{tabular}{|lll|}
\hline $\begin{array}{l}\text { Greater Mekong Sub-region } \\
\text { (GMS) }\end{array}$ & $\begin{array}{l}\text { Mekong River Commission } \\
\text { (MRC) }\end{array}$ & $\begin{array}{l}\text { Quadripartite Economic } \\
\text { Cooperation (QEC) }\end{array}$ \\
\hline Vietnam & Vietnam & $/$ \\
\hline Cambodia & Cambodia & $/$ \\
\hline Laos & Laos & Laos \\
\hline Thailand & Thailand & Thailand \\
\hline Myanmar & $/$ & Myanmar \\
\hline China & $/$ & China \\
\hline
\end{tabular}

\subsection{Imperfect water pollution legislation}

The Mekong River is a transboundary river, flowing through six riparian states with different, imperfect and impertinent water legislation and policies. If there were no unified laws and regulations regarding the trans-boundary river basin level, current agreements would easily collapse.

Existing conventions and agreements include the Joint Declaration of Principles for Utilization of the Waters of the Mekong Basin, Agreement on the Cooperation for the Sustainable Development of the Mekong River Basin, The Greater Mekong Sub-Region Economic Cooperation Program Strategic Framework and Kunming Statement. These conventions and agreements were established for basin management and international cooperation with no legal standing. In addition, these conventions and agreements are not signed by all six riparian countries, so they cannot accomplish comprehensive water pollution management [9].

\subsection{Lack of information and data}

It has communication barriers. At present, an instrumental database has been established for the Mekong River basin, headed by the secretariat of the MRC. According to the majority of studies in the last 40 years of the Mekong, there are appropriate condition for hydrological research and reviews of hydrological trends. However, on the whole, the information is out of date and incomplete, especially regarding the field of deforestation, soil erosion and sediment deposition.

\section{RECOMMENDATIONS}

\subsection{Cooperation in the Mekong River Basin}

The current management organizations of the Mekong Basin do not have specific departments dedicated to controlling water pollution; China manages the upper Mekong River and the MRC manages downstream [9]. Due to disagreements between upstream and downstream countries, China should ideally adopt targeted cooperation in selected fields with the MRC (something downstream countries are encouraging) to promote integrative management, cooperation and ensuring safety of water resources of the Mekong Basin. The cooperation topic should deal with issues of concern such as ecological environment protection, hydropower development and climate change. Water resource development involves the interests of multiple parties, meaning international cooperation must be conducted gradually. Besides the MRC, there are many organizations in the Mekong River with similar functions and issues. For example, the GMS also focuses on environmental governance in the Mekong. As a result, through strengthening cooperation on improving environmental conditions, China in the GMS can promote forest and fish protection in the Mekong Basin, allowing the GMS to play a more prominent role in the future [11].

\subsection{Improvement of supervision}

A supervision system should be established for the entire Mekong River. The supervision system needs to formulate as soon as possible and be adapted for a local context, such as a unified environmental standard, joint detection, public participation, information sharing and pollution control. The management of the Mekong River Basin does not adhere to current supervision measures. Strengthen supervision should be based upon the establishment of regulatory agencies. Besides the function of supervision, the regulatory agencies should have supporting roles, such as penalties and evaluation schemes [12].

\subsection{Public participation and multi-participation}

Public participation and multi-participation are necessary in dealing with various conflicts of interest. Public participation such as policy making and planning from engineers, politicians and landowners is significant in the decision-making process of resource management [13]. Protection of the Mekong environment is not only the duty of the government, but also that of factories, enterprises and residents. For water quality management of the Mekong River, public participation and multi-participation will play a vital role [14]. NGOs promote the environmental governance in the Mekong River, working in fields such as providing environmental information, supervision of environmental cooperation, environmental research and promoting basin countries cooperation [15]. As NGOs, if more water protection organizations and industry associations participate in important decision-making process, the decisions and policies will as a result be more transparent and practicable [16].

\section{CONCLUSION}

The water resources of the Mekong River should be developed as a whole. The best way to develop the Mekong river should include mutual coordination and shared interests. Although there are many problems in the Mekong region, it still has opportunity for the whole Mekong River Basin countries. In addition, riparian countries are gradually increasing cooperation concerning water resource development.

The Mekong region is one of the areas with the most substantial natural accumulations of water resources. The protection of the ecological environment is also a key focus. Drawing experience from the successful management of other country, the Mekong River Basin can have sustainable ecological development. However, the riparian countries must work closely with each other to reap the benefits. The governments of the lower Mekong Basin have promised to increase data collection efforts and to share data, improving decision making for trans-boundary water sharing in the basin. Although China and Burma are still not members of the MRC, there is increased cooperation among them. The Greater Mekong Sub-region, which includes all six riparian countries, also focuses on basin development and environmental protection. There will be more cooperation of the whole riparian state.

\section{REFERENCES}

[1] Gupta, A. D. 2005. Challenges and opportunities for integrated water resources management in Mekong River Basin. In International Symposium on the Role of Water Sciences in Transboundary River Basin Management, 10-12 March 2005. Thailand: Asian Institute of Technology.

[2] He, D., Feng, Y., Gan, S., Magee, D., and You, W. 2006. Transboundary hydrological effects of hydropower dam construction on the Lancang River. Chinese Science Bulletin, 51 (22), 16-24.

[3] Goh, E. 2004. China in the Mekong River basin: the regional security implications of resource development on the Lancang Jiang (RSIS Working Paper, No. 69). Singapore: Nanyang Technological University.

[4] Hinton, P. 1998. Resource management in the Yunnan Mekong basin (No. 72). Asia Research Centre, Murdoch University.

[5] Buxton, M., Kelly, M., and Martin, J. 2003. Environmental conflicts in the Mekong River Basin, Report to the Mekong River Commission, School of Social Science and Planning, the Royal Melbourne Institute of Technology. RMIT University.

[6] Hirsch, P., and Cheong, G. 1996. Natural resource management in the Mekong River Basin: Perspectives for Australian development cooperation.

[7] MRC. 2008. An assessment of water quality in the Lower Mekong Basin. In Ongley, E. \& Burnhill, T. (Eds.), MRC Technical Paper No.19. Lao PDR: Mekong River Commission.

[8] Myint, T. 2003. Democracy in global environmental governance: issues, interests, and actors in the Mekong and the Rhine. Indiana Journal of Global Legal Studies, 10 (1), 287-314.

[9] Du, J. 2010. Water pollution prevention and control mechanism of Lancang-Mekong River- European river pollution management experience (master's thesis), Kunming University of Science and Technology, China. 
[10] Hensengerth, 0. 2009. Transboundary river cooperation and the regional public good: The case of the Mekong River. Contemporary Southeast Asia: A Journal of International and Strategic Affairs, 31 (2), 326-349.

[11] Deng, H. 2011. Game-playing of Lancang-Mekong River water resources (master's thesis). Jinan University, China.

[12] Wang, X. 2012. Research on the Cooperation Mechanism of Lancang-Mekong River Water Resource. Around Southeast Asia, (10), 73-76.

[13] Chen, L. H., Zeng, Z. G., and He, D. M. 2003. Coordinating the relationships between interest parties in development of the international river-A case study of Lancang-Mekong. World Regional Studies, 12 (1), 71-78.

[14] Chen, S. R. 2008. A review on environmental cooperation in Great Mekong Sub- region-lessons from Rhine River Regulation. Journal of Yunnan Normal University, 28 (5), 69-74.

[15] Tang, H. X. 1999. Water resources in the Lancang-Mekong River Basin and analysis on the present situation of its utilization. Yunnan Geographic Environment Research, 11 (1), 16-25.

[16] Ringler, C., von Braun, J., and Rosegrant, M. W. 2004. Water policy analysis for the Mekong River Basin. Water International, 29 (1), 30-42. 